\title{
Oral Tradition in Pantun of Langkat Malay Traditional Wedding Ceremony
}

\author{
Muhammad Natsir ${ }^{1}$, Bakhrul Khair Amal' ${ }^{2}$,Supsiloani ${ }^{3}$, Rita Suswati ${ }^{4}$ \\ 1,4 Faculty of Languages and Art, English Department of Universitas Negeri Medan, Indonesia \\ 2,3 Lecturer in Social Science Faculty of Universitas Negeri Medan, Indonesia \\ mnatsir@gmail.com,
}

\begin{abstract}
The purpose of this study was to conduct the oral tradition in Pantun of Langkat Malay traditional wedding ceremony by using Sibarani's theory. Oral Tradition itself is text, co-text, and context tradition. The method used in this paper was descriptive and qualitative. For collecting the data the researcher became an instrument by doing observation and unstructured interview. Analysis technique used which were transcribing, reading, comprehending, investigating, describing, and explaining. The findings of text showed theme in Pantun that uttered by telangkai contained gratitude, honor, tradition, persuasion, joke, hoping a kindness, signifying a peace, welcoming guest, enthusiastic, teasing which briefly supported by co-text and context. Co-text described paralinguistic, kinetic, proxemic, and material elements. Some context applied as follow; cultural context, social context, context of situation, and culturalcontext.
\end{abstract}

Keywords: text, co-text, context, pantun, langkat Malay traditional wedding ceremony

\section{Introduction}

Every human in this world has a culture. Culture itself is knowledge, belief, behavior, outlook, attitudes, values, goals, traditions, and practices shared by a group of people that cannot be attributed to genetics. It can be defined that culture is as the universal human ability to encode and transmit experiences symbolically. And mostly they respect their culture to become a tradition which can be important and sacred value orit can be the guidance for their life, for instance oral tradition. Thus, oral traditions are the community's traditionally cultural activities inherited from one generation to generation, either the tradition is verbal or non-verbal (Sibarani, 2012:47).

In this research the researcher analyzed Langkat Malay. One of an oral tradition custom in their traditional wedding ceremony of Langkat Malay is Pantun in palangpintu or empangpintu which in this section, bridal party from groom and bride will utter Pantun. Supported with preliminary data by asking, currently not all young generations in Langkat totally understand when thePantun conveys during palangpintu custom. They just listen without realizing the meaning and the reason why the Pantun is uttered. Perhaps one of the factors is global culture or modernization, like in daily activity they pass Malay language, use another slang language which is more modern, just use bahasa (language) to communicate each other, or they are reluctant toinherit.

Based on that phenomenon the researcher wanted to dig up, investigate, and interested in analysing the oral tradtion in Pantun. The oral tradition itself is text, co-text, and context in Pantun that is exist in palangpintu (Sibarani, 2012:322). Text, co-text, and context become a formation that could be analyzed by using anthropolinguistics studies. Antrhopolinguistic is a branch of linguistic which deals with language and human life including human's culture. According to Sibarani (2012:322) anthropolinguistics studies the oral tradition into several parts firstly to find the formation from text, co-text, and context, secondly to dig up values and 
norms that could be interpreted based on meaning, message, and the function of oral tradition (content), thirdly is to investigate the local wisdom which could be applied in daily life, lastly is a revitalization process to manage inheriting the oral tradition. And in this research just focuses on part which structure or form of oral tradition in antrhopolinguisticsstudies.

The researcher deals with text, co-text, and context because supported by some previous research that have already done. First Winona, Sinar, Sibarani, and Takari (2017) their research entitled "The Performance, Text, and Context Cenggok Cenggok Malay PanaiLabuhanbatu" the result of spoken text CenggokCenggok showed theme of the text in pantun, and context of poems and rhymes are described and analyzed including cultural context, social context, the context of the situation, and ideological context. Another research declared by Puspitasari (2015) entitled "PenelitianTerhadap Struktur Cerita, Konteks, Koteks, Proses Pewarisan, Fungsi, Nilai-Nilai, dan Ancangan Model Revitalisasi Tradisi Lisan Jemblung JawaTimur" explained the findings in that study include: the structure, aspects of context (cultural, social, situation, ideology), aspects of co-text, the process of inheritance, the function of the oral tradition as follows jemblung values are found in the oral traditions jemblung dominated by religious values and cultural values. Last "Batombe: Warisan Budaya Bangsadari NagariAbai Provinsi Sumatera Barat" by Eva (2016). In her studies towards Batombe have done in observing 3 things, as follow: context, text, andco-text.

So, from these relevant studies the researcher obtains a concept or description of the theory and information that became a reference or comparison for the researcher to explore issues about text, co-text, and context in Pantun of palang pintu custom in Langkat Malay traditional wedding ceremony.

\subsection{Anthropolinguistic}

\section{Review of Literature}

This research focuses on analyzing oral tradition based on antrhopolinguistics studies. Formation itself is text, co-text, and context. Text is the unity of language which regards to written or spoken that aims to understand the meaning. In oral tradition, a text often accompanied by elements of nonverbal called co-text. And co-text in oral tradition according Sibarani (2012:333) can be divided into paralinguistic, kinetic, proxemic, and material elements. Co-text may also serve to clarify the message or meaning of an oral text, but may also have its own meaning in an oral tradition. The role of context is also very important in studying oral tradition, because the meaning of the elements of the text in oral tradition is highly dependent on the context. According Sibarani (2012:338) kinds of context are cultural context, social context, situation context, and ideology context

\section{A. Pantun}

Pantun is one of the old forms of poetry which is still favored in this modern area by the people of Indonesia. Pantun is still used as in the association daily, singing, and language in speech (especially in the end). This is not surprising because of the Pantun indeed original from Indonesia (Rismawati, 2017:57).Winarni (2010:6-7) also mention several characteristic of Pantun, as follow:

- It has fourlines.

- Every line consists of 8 until 12 syllables but commonly 10 syllables.

- The first two lines are called sampiran.

- The last two lines are called content isi.

- And Pantun has rhymes a-b-a-b. 
Each pantun consists of two parts: sampiran and content isi. The first two line often related to nature, and usually have no connection with the second part which involves intention than to deliver rhyme. The last two lines are the content, which is the purpose of the Pantun. Pantun divided into According to Rismawati (2017:58) Pantun has a function, as follows:

- Pantun serves as a word and the ability to maintain the flow thinking.

- Train someone to think about the meaning of the word before saying.

- Train people thinking associatively, that a word can have connection with other words.

\section{B. Langkat Malay Traditional Wedding Ceremony}

Mengantar Pengantin in Langkat malay according to Arifin (49:2009) divided in to 8, as follow: empang batang, empang halaman, empang pintu, empang pelaminan, empang kipas, tepung tawar, makan nasi hadap-hadapan, serah terima. But recently empangan has been simplified become three.Empang pintu or Palang pintu is only stretching cloth in each end held by anak beru to prevent the groom and entourage. By the time the groom comes along with the entourage, they should not go straight in but must stop first and they will be greeted by the bride. Usually in this section there are an action Malay dance as welcome speech, after that to get into the bride's house, the telangkai of groom and bride will return Pantun first, and if the telangkai of the groom can reply the Pantun from the traditional stalks of bride, then the groom's entourage can enter through the first palangpintu and so on as much as how many palangpintu that's made before by the bride. The meaning that can be taken from palangpintu custom is the groom must ask permission to the family of the bride to ask for her as a wife, and the man must be willing to be asked about his ability to marry the bride become his wife someday. Then the groom must also be able to fulfill the needs of his wife later both in terms of material and also non materials.

\section{Methodology}

This research be conducted by descriptive and qualitative. According to Kothari (2004:2) the major purpose of descriptive research was description of the state affairs as it exists at present. Qualitative research, research was concerned with subjective assessment of attitudes, opinions and behavior (Kothari,2004:3). The researcher became an research instrument to obtain the data through observation and interview. The data were all the utterences about Pantun in palang pintu custom. After getting the data firstly the researcher analysed text meaning (theme) in each Pantun, then continued analysing the co-text which divided into paralinguistics, kinetic, proxemic, and material elements. Last, investigated kinds of context such as culture, social, situation, and ideology which applied in Pantun. Text, cotext, and context in Pantun analyzed by using Sibarani’s theory (2012).

\subsection{Text}

\section{Discussion}

In this study were found 25 Pantun inwhich every text of Pantun in palangpintu customof Langkat Malay traditional wedding ceremony had various themes. 


\begin{tabular}{|c|l|c|}
\hline No & Kinds of Pantun & Numbers of Pantun \\
\hline 1 & Pantun adat & 9 \\
\hline 2 & Pantun mulia & 2 \\
\hline 3 & Pantun sukacita & 3 \\
\hline 4 & Pantun jenaka & 11 \\
\hline \multicolumn{2}{|c|}{ Total } & 25 \\
\hline
\end{tabular}

Table 1. Kinds of Pantun

From the 25 Pantun, there were found kinds of Pantun. The samples of the classification about Pantunin palangpintu customwere presented below;

Pantun adat

Jalan setapak menuju tepian Kelana pulang syarat muatan

Terimalah tepak sebagai persembahan Lambang adat tanda kehoramatan

The content of the first text has theme like giving gratitude from groomand his entourage for the bride and his family because their coming were warmly welcomed, then when deliver the Pantun was accompanied by giving tepak as the symbol of honor.

Pantun mulia

Terbang hinggap siburung merbah

Membuat sarang di pohon jati

Pinang menghadap pinang menyembah

Jari sepuluh menyusun duli

The text had a theme like giving a honor, the meaning of duli that was uttered by telangkai meant honor.

Pantun sukacita

Sungguhlah kami merasa senang

Melihat pangeran dan rombongan sampai kesini Tendengar

kabar pangeran dan rombongan hendak datang Berkumpul

kami seluruh sanak dan family

From the Pantun above the telangkai informed that the arrival of groom and his family have been already waiting, so the situation pictured if families from bride were very enthusiastic for welcoming the groom and his family.

\section{Pantun jenaka}

Burung merbah siburung tiung

Terbang hinggap kedalam hutan

Orangnya gagah hidungnya pun mancung

Mirip bintang AmitaBachchan

The text of the Pantun had a theme like tease that the telangkai attempted to persuade the guard who hold the stretching cloth to open it. 


\subsection{Co-text}

As explained before that co-text became one of the important part in interpreting meaning to the text of oral tradition. Sibarani (2012) was divided into: paralinguistic (suprasegmental), kinetic (gestures), proxemic (distance guarding), and material elements or objects used.

1. Paralinguistic

The suprasegmental element in th ePantun could be seen in the intonation and stress that a rised while uttering Pantun. So that the intonation that was raised in each Pantun was almost the same, namely the stress of intonation happened on the first word or the next following word,thendecreasing the intonation stress on the last word.

'Burung 'merbah siburung tiung Terbang

hinggap kedalam hutan

Orangnya gagah hidungnya pun mancung Mirip bintang

AmitaBachchan

\section{Kinectic}

When people have a talk, it is usually accompanied by certain movements, such as hand movements, head nods, showing expressions, body movements and so on. It may give its own meaning if the usage of the movements separate from the text, or just accompanied the text to explain the meaning completely. In Langkat Malay traditional wedding ceremony was found that there was not particular movement because the use of movement had a function to clarify the text of oral tradition. This dancer's gesture described an honor, gratitude, welcoming guest of the bride's coming which followed

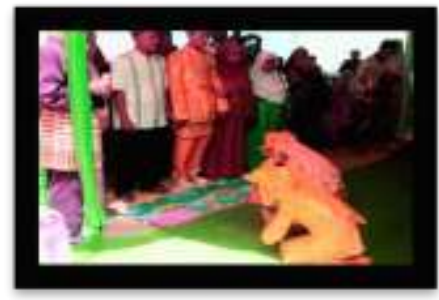

by the text.

Lenggak lenggok gadis menari Tangan diayun kekanan dan kekiri

Terimalah tarian sebagai persembahan kami Untuk

menyambut tamu kebanggan negeri

3. Proxemic

A description of proxemic (guarding distance) both of the telangkaicould be seen if there was a clear blocking which not too close and not too far away so the text could be heard clearly. While the speakers and listeners had no special distance in order anyone could enjoy this tradition from any side they wanted.

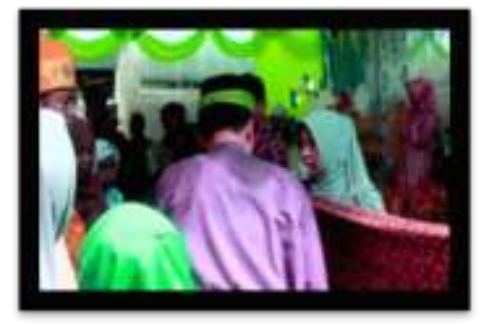


4. Material Element

a) Tepak Sirih; In Malay traditional wedding ceremony tepak was used for welcoming guest, a tool for opening communication by telangkai. In addition were able to Signify a peace due to there was an agreement of each other after exchanging tepak. Usually tepak was filled with various kinds such as kapur, sirih, tembakau, gambir which has their own meaning.Kapur gave a symbol of a pure white heart and sincere. Sirih had a symbol of humility, and always glorifying people. Tembakau symbolized a steadfast heart and a willingness to sacrifice in everything. Gambir had a bitter tate symbolizing determination, it was understood that before reaching something, we had to payienly carry out the process to achieveit. But in this research itwas just a symbol without being filled by anything.

b) Kain panjang; Kain panjang symbolized a door that guarded by both men standing right and left. Kain panjang jarik from Java had a function as hulu balang who block a king. Seeing the door blocked by the two young men, then there was a replying Pantun from both of the telangkai. Palangpintu had become a custom of Langkat Malay society from a long time ago. And the door could be opened if the groom's family could provide the requirement first, and show the bride's that his fingers used the henna.

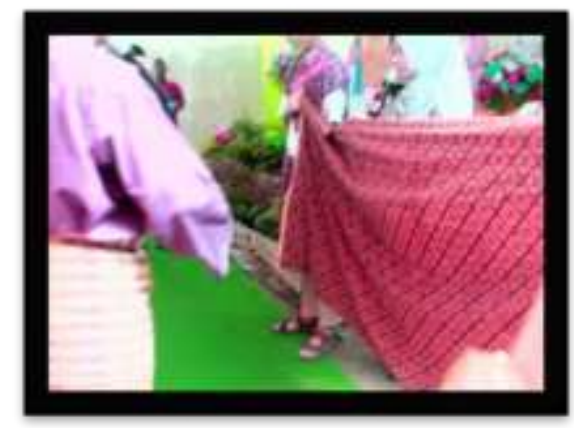

c) Uncang; There was money in uncang, nowdays the real uncang was replaced by anvelope because it was hard to find someone who wanted to made it. So to make it easy people in this modren area did not used the real uncang anymore. The use of uncang (anvelope) amied to persuade to ask the two guard to open the door that they hold. In bahasa called it as tanda damai. The uncang was given to the man and followed by uttering text like;

Terbang tinggi siburung merbah

Terbang jauh kedalam hutan

Ini uwak bawa hadiah

Untuk besok kau beli jajan

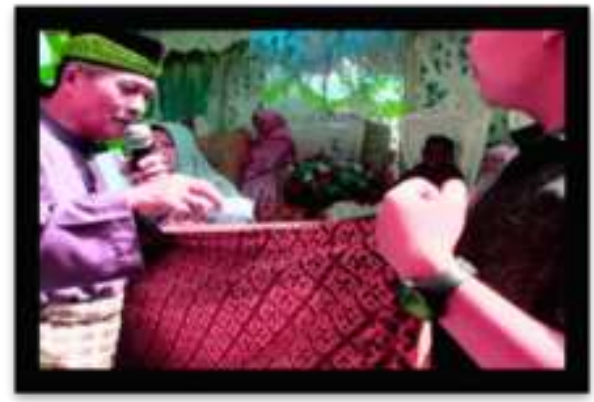




\subsection{Context}

\section{Cultural Context}

The cultural context refered to te cultural event it meant an event also influences the spell text used. For example the use of Pantun in traditional wedding ceremony was certainly different from the used in Pantun in circumcision. And Pantunwhich used in wedding ceremony was certainly different from Pantunused in religious events such as preaching, or other events in Malay customs.

This was caused by differences in the goals to be achieved in every single event. In Malay traditional wedding ceremony, the text of Pantun told about like a wishes in married, grattitude, giving an honor, welcoming guest, entertainment, joke, makig persuasion, giving a teasing. Thus, we can understand that the use of a Pantun depends on the goal of event itself.

\section{Social Context}

The social context in this study referred to the people involved in the wedding, namely telangkai and audiences.

a) Telangkaiwho performed the text of Pantun in palang pintu custom there was not limited to sex, social class, and educational background for someone who wanted to be a telangkai, but the most important thing that he or she was an adult and married in order to be able to give advice to bride and groom.

b) The audiences, all people were involved in Malay traditional wedding ceremony men and women from toddlers to elderly could enjoy it. People who came from everywhere could also watch this event though they came from uptown, suburb, abroad. There was no exception for someone that involved this event.

\section{Context of Situation}

This context refers to time, place, and how the way of performance in an oral tradition. The process of delivering Pantunin palangpintuusually took a place at the bride's home at around 10 am in that time guest particulary family from groom and bride have started to come thus the event could be more intimate, the situation pictured very crowded because every member of family from bride and groom, and invited guests were very enthusiastic and happy to watch the event of that oral tradition. It was seen when some of them laughed happily when Pantun was uttered each other

It was well known since a long time ago if yellow color became an idendity of Malay. The color of yellow had a symbol of holiness. And in this oral tradition was also full of yellow. Thenthe performance in this oral tradition commonly was not too much different from the previous tradition, in the use of language which still contained figurative language as well known it was a characteristic of Malay people from a long time ago. But there were some things that followed with current modrenisation, such as it the use of uncangreplaced with envelope.

\section{Ideological Context}

Sibarani argued that the ideological context refers to the power that influence and dominate a text. Ideology was the understanding, beliefs, and values shared by the community. In addition idoelogy was a body of beliefs or principles belonging to an individual or group. The majority of the Langkat Malay people were mostly Moslem 
whose beliefs affect a custom and tradition, Islam gave the big influance of Malay, they followed the rule and be a guidance for their life particularly in the process of marriage. The use of Pantun because the society followed Malay custom that already existed before. Pantun became a polite communication tool that would not hurt, so it's very appropriate with Islamic religion which guided us to don't be rude while speaking.Thus, it could concluded that traditional was an ideological mix between Islam and Malay.

\section{Conclusion and Suggestions}

The research findings after analysing the Pantunof palangpintucustomin Langkat Malay traditional wedding ceremony. The theme in Pantun had a correlation to the culture or tradition of Langkat Malay traditional wedding ceremony. The fact some words selected to picture the tradition itself. The co-text was found in Pantunnamely paralinguistic that describesd an intonation, stress, pause. Kinetic deals with gesture, there is no special gesture found. Proxemic explained blocking of speaker and listener. Material element used which were tepak, kainpanjang, uncang. All contexts that applied were cultural context, social context, context of situation, and ideological context. Cultural context refers to cultural events, the social context concerned towards telangkaiand audiances. Context of the situation was how the situation and the way of performance in that event, and the ideological context explains what ideology that dominated the oral tradition.

After doing research in the field, then obtained the data and information in accordance with the required to research purpose, the researcher would like to give suggestion and hopefully can be useful for the development of thinking for the continuity of a process of unity and the nation. For the further research, the researcher suggest to next researcher to expand the object of Malay tradition not only palangpintubut also another tradition such as empangbatang, empangpelaminan, makannasihadap-hadapanso the result of the analysis would be more comprehensive. Furthermore to make the research is more challenging and try to compere the representation of formation. Or the next researcher be able to continue this research to dig up value and norms, local wisdom, and how to make a revitalization in Pantunof palangpintuin Langkat Malay traditional wedding ceremony.

The readers and audiences especially young generation of Langkat Malay be understood of the formation in Pantunof palangpintuin Langkat Malay traditional wedding ceremony. The message may be positive, but the core intention in presenting the Pantun as oral tradition is to show if Langkat Malay still respect the custom and tradition since a long ago.

\section{References}

Arifin, Zainal. 2009. Adat Budaya Resam MelayuLangkat : Mitra Medan.

Arikunto, Suharsimi. 2010. Prosedur Penelitian Suatu Pendekatan praktik. Yogyakarta: Rineka Cipta.

BPS, Statistic of Langkat Regency. 2010. Langkat Regency in Figures 2010.

Duranti, A. 1997. Linguistic Anthropology. Cambridge: Cambridge University Press.

Hoed, Benny H. 2008. Semiotik dan Dinamika Sosial Budaya. Jakarta: FIB-UI

Kothari. 2004. Research Methodology Methods and Techniques: New Age Internasional. 
Krisna, Eva. Batombe : Warisan Budaya Bangsadari Nagari Abai Provinsi Sumatera Barat. Madah, Volume 7, Nomor 2, EdisiOktober 2016:159-166.

Moss, William W. and Peter C. Mazikana. 1986. Archives, Oral History and Oral Tradition a RAMP Study. General Information Programme and UNIS1ST.Paris :Unesco.

Pateda, Mansoer. 2001 Semantik Lekasikal. Jakarta: PenerbitErlangga.

Puspitasari, Peni. 2015. Penelitian terhadap Struktur Cerita, Konteks, Ko-teks, Proses Pewarisan, Fungsi,Nilai-Nilai, and Ancangan

Revitalisasi Tradisi Lisan Jemblung Jawa Timur. E-mail: penipuspitasari89@yahoo.com. ISSN 1412-565 x.

Rismawati.2017. Perkembangan Sejarah Sastra Indonesia. Banda Aceh: Bina Karya Akademika.

Safnil. 2010. Pengantar Analisis Retorika Teks. Bengkulu: FKIP UNIB PRESS.

Saragih, Amrin. 2014. Discourse Analysis: Medan.

Saragih, Amrin. 2006. Bahasa dalam Konteks Sosial. Medan: Pascasarjana Unimed.

Sibarani, Robert. 2012. Kearifan Lokal : Hakikat, Peran dan Metode Tradisi Lisan.

Jakarta: Asosiasi Tradisi Lisan.

Sugiyono. 2016. Metode Penelitian Kuantitatif, Kualitatif dan $R \& D$. Bandung: IKAPI.

Takari. Zaidan and Fadlin. 2014. Adat Perkawinan Melayu : Gagasan, Terapan, Fungsi, dan Kearifannya. USU press.

Winarni, Sri. 2010.Bunga Rampai Pantun.Trawa : TB PustakaIlmu.

Winona. Sinar.Sibarani.And Takari.The Perfomance, Text, and Context Cenggok- Cenggok Malay Panai Labuhan batu - Sumatera Utara, Indonesia. Volume 06, issue 07, 2017, 55-61.https://www.tutyqueen.com/2016/02/budaya-palang-pintu-pada-perkawinan.html. (accessed at 15.40, On 18 March) 